Article

\title{
Post-Truth as a Mutation of Epistemology in Journalism
}

\author{
Pablo Capilla
}

Blanquerna Institute of Research in Communication and International Relations, Ramon Llull University, 08001 Barcelona, Spain; E-Mail: pablocg@blanquerna.url.edu

Submitted: 31 July 2020 | Accepted: 12 November 2020 | Published: 3 March 2021

\begin{abstract}
In recent years, many authors have observed that something is happening to the truth, pointing out that, particularly in politics and social communication, there are signs that the idea of truth is losing consideration in media discourse. This is no minor issue: Truth, understood as the criterion for the justification of knowledge, is the essential foundation of enlightened rationality. The aim of this article, based on prior research on social communication (especially as regards journalism), is to elucidate an explanation of this phenomenon, known as 'post-truth.' Because it is an epistemological question, the three main variables of the problem (reality, subject and truth) have been analysed by taking into account the manner in which digital social communication is transforming our perception of reality. By way of a conclusion, we propose that (a) the ontological complexity of reality as explained by the news media has accentuated the loss of confidence in journalism as a truth-teller, and that (b) truth is being replaced by sincerity, as an epistemological value, in people's understanding of the news. The result, using Foucault's concept of Regime of Truth, suggests a deep change in the global framework of political, economic, social and cultural relations, of which post-truth is a symptom.
\end{abstract}

\section{Keywords}

epistemology; fake news; journalism; ontology; post-truth; reality; social media; truth

\section{Issue}

This article is part of the issue "Disinformation and Democracy: Media Strategies and Audience Attitudes" edited by Pere Masip (Ramon Llull University, Spain), Bella Palomo (University of Málaga, Spain) and Guillermo López (University of Valencia, Spain).

(C) 2021 by the author; licensee Cogitatio (Lisbon, Portugal). This article is licensed under a Creative Commons Attribution 4.0 International License (CC BY).

\section{Introduction}

The idea of 'post-truth' may evolve into a 'zombie concept' if its meaning is not determined and if it fails to show some kind of capacity to explain our reality. Since its popularisation in 2016, following the victory of Donald Trump in the US and Brexit in the UK, post-truth has come to form part of public and academic discourse. However, in social communication, it has only been used to designate a vague series of phenomena: fake news, disinformation, loss of trust in the media, the 'emotional turn' caused by the influence of social media (Wahl-Jorgensen, 2016) and, above all, the rise of populism, aided by political communication practices. The epistemological implications of post-truth have hardly been analysed, despite the fact that it is clearly an epistemological concept, since it deals with truth, that is, with the validation of statements about reality.
Philosophy, for its part, has shown little interest in post-truth. Susan Haack (2019) admits that perhaps concern for truth is on the decline, but that does not imply that the idea of truth is in crisis. For Lorna Finlayson, post-truth is nothing more than an 'act of saying':

What, finally, is being done with the word 'posttruth' when it is used? As with the sort of political speech it is used to talk about, talk about posttruth appears to make little sense when taken at face value: It is either totally banal...or it is both wildly audacious and philosophically confused. (Finlayson, 2019, p. 78)

These authors argue that the idea of post-truth adds nothing new, only more confusion, because it is an imprecise and politically charged term usually reserved for discrediting opponents. 
However, research in various academic fields indicates that in recent decades there has been a deep transformation not only of the material means (economic and technological) of our societies, but also of the social structures and the forms of subjectivity in which these material means act (Boler \& Davis, 2018), and that this could be affecting the idea of truth. Part of this approach revolves around 'neoliberalism,' understood not only as an economic theory and practice, but as an alternative to enlightened rationality that affects the way in which people perceive themselves, others and reality. Wendy Brown defines neoliberalism as "an order of normative reason that, when it becomes ascendant, takes shape as a governing rationality extending a specific formulation of economic values, practices and metrics to every dimension of human life" (Brown, 2015, p. 30).

Researchers in the fields of general sociology (Gane, 2014), cognitive sociology (Leyva, 2020), social psychology (Gjorgjioska \& Tomici, 2019) and education (Goldstein, Macrine, \& Chesky, 2011) have also pointed in the same direction.

This is how the central question of this article arises: Do post-truth and neoliberal subjectivity refer to similar things? Is this means of naming phenomena associated with neoliberalism? Does post-truth specifically refer to an epistemological mutation caused by these phenomena? Obviously, these are not new questions: authors such as Calin Cotoi (2011), Barbara Biesecker (2018) and Sergei Prozorov (2019) have linked post-truth to neoliberalism under the Foucaultian concept of 'Regimes of Truth' (RoT), which defines the general framework in which the relationship between truth, power and subjectivity is established. It is not the aim of this article to engage in a debate on the notion of RoT, nor whether Foucault is at the philosophical origin of post-truth (Mclntyre, 2018), but to propose an explanation for the change that may be occurring in the perception of the truth within the framework of this neoliberal rationality. For this, we turn to previous studies on the issue conducted within the field of journalism, since journalism is a gnoseological activity.

Thus, this article seeks (a) to problematise journalistic ontology, in line with other authors, as the first step to addressing the issue of the validation of statements about reality: We start with ontology, because, without knowing the facts, it makes no sense to consider the possibility of knowledge, and journalism has tended to uncritically accept that facts simply exist. The hypothesis is that, if the news media were to spread different types of reality, it would be impossible to establish a single epistemological justification, and doubts might even be cast about the very idea of verifying facts. Next (b), we will analyse how these problematic journalistic facts are being validated in a digital media context: We place this question in the conceptual framework in which post-truth and neoliberal rationality converge, using the Foucaultian concept of RoT because it enables us to integrate the subjective dimension into the gnose- ological process, and because it explains how epistemology is determined by the neoliberal hegemony.

\section{Theoretical Framework}

Discussion surrounding the concept of truth falls within the ambit of knowledge, i.e., what do we know, how and to what certainty, and revolves around three factors: (a) reality (ontology)-what we want to know, which entails the implicit acceptance that something outside the subject exists; (b) the subject-the individual who makes statements based on their perception of realitythese statements emerge as a conviction that what they are saying is what they have perceived (sincerity) and are shared with other subjects with a view to instilling in them the same conviction; and (c) truth as a shared criterion for justifying statements about reality. This is what gives others a reason to accept the statement and subsequently hold it as true.

According to Bernard Williams, knowledge is based on the values of 'sincerity' (people believe what they say) and 'accuracy' (what people say is caused by contact with reality and may be checked against reality). Sincerity pertains to the subject, to their beliefs, and entails a willingness to ensure that our statements about reality express what we really believe. Sincerity therefore also has a social dimension, since it is assumed that whoever communicates something wants others to share their idea:

The connections between belief and truth explain why, in the case of sincere assertion, a speaker's intention to inform the hearer about the truth, and to inform him about the speaker's beliefs, fit naturally together-they are two sides of the same intention. (Williams, 2002, p. 75)

Accuracy refers to the methods used to justify the statements, drawing a distinction between methods which prove more reliable than others when it comes to reflecting reality. But accuracy requires sincerity, because a person can lie using exact data: What prevails in the lie is the issuer's willingness to hide what they really think in order to manipulate the reality they present to others, effectively trapping them by their will. According to this idea of knowledge, accuracy corrects the false security that sincerity can provide, by establishing the need to contrast the inner sense of security we have that we are telling the truth with some external element, allowing us to share and reinforce this sense of security with others. Thus, a gnostic statement would be a 'justified belief': "One that is arrived at by a method, or supported by considerations, that favour it, not simply by making it more appealing or whatever, but in the specific sense of giving reason to think it is true" (Williams, 2002, p. 129). The problem here lies in adequately justifying that what is said is true. This is the key question in epistemology. To refrain from providing a detailed description of this 
endless philosophical discussion, we will focus on the issues most relevant to the epistemology of journalism.

The most persistent justification of knowledge is the suspicion that there is some correspondence between statements and reality. Thus, what we say about reality is reality. The simplest expression of this concept is the 'Tarski sentence': 'Snow is white' (statement) is true if and only if snow is white (reality). This is the approach inherent to the correspondence theory (Haack, 2019), which associates reality and truth, yet omits the subject, who is perceived as a contaminant, because the subject introduces their biases into their statements about reality. This is the basis of the idea of objectivity in journalism, characterised by the strict separation of information (pure facts, reality) and opinion (values, the subject; Maras, 2013).

The problem with the 'Tarski sentences' is that they only work with very simple logical-formal statements, but not with news: Readers are rarely able to verify a statement against their perception of the events. Correspondence also raises a circular problem: To justify a statement generated based on a perception, we need another perception of the reality, which is what we want to justify. The only way to escape this vicious circle is through a metaphysical justification, as posed by Aristotle: Between reality and statements there is a shared essence, logos.

Pragmatist philosophers avoided this metaphysical dimension by invoking utility: The truth depends on its practical results, on what we can do with it, i.e., it may be verified in reality. Pragmatists advocate a form of truth based on 'common sense,' which people apply to their lives without asking themselves big questions (Frankfurt, 2007), because, in pragmatism, the debate about what is the truth is of little importance: According to Charles $\mathrm{S}$. Peirce, truth is the result of an inquiry that is carried on indefinitely, an idea applied to verification in journalism (Kovach \& Rosenstiel, 2007).

Despite their differences, the correspondence and pragmatic theories of truth share an imperative view of the truth: It is the judge that resolves whether or not what we say is correct, and once established, the truth is necessary, at least until there appears another truth that explains reality better. The imperative nature of truth, the result of the universal sense of reason that emerged during the Enlightenment, has been the subject of constant criticism over the past century (Falomi, 2019).

Constructivist epistemology tempered this imperative nature by focusing on the social processes that construct reality, turning it into a 'social reality,' which, according to Niklas Luhmann (2000), is the result of communicative processes. While constructivism does not deny the existence of an external reality, it considers it of secondary importance, reduced to the mission of providing materials to build the social reality. And by dissociating the social reality from the physical reality, the question of truth becomes blurred. Studies in the field of journalism began integrating constructivism with
Gaye Tuchman (1978): Journalism does not reflect reality, it constructs it (Poerksen, 2011), with the risk of anti-realism and relativism that comes with bracketing its ontological basis (Hearns-Branaman, 2016).

Foucault also rejects correspondence and imperative truth, yet approaches the issue differently: He goes beyond epistemology and frames it within a broader concept, the RoT, which is chiefly concerned not with how reality is constructed (as in constructionism), but with how truth is produced (giving truth an historical and contingent character):

By 'truth' it is meant a system of ordered procedures or the production, regulation, distribution and circulation of statements....'Truth' is linked by a circular relation to systems of power, which produce it and sustain it, and to effects of power, which it induces and which redirect it. (Foucault, 1977, p. 14)

The RoT is structured around power and subjectivity: Power imposes its interpretation of reality (what is true) on the individual, and the individual constructs their subjectivity by integrating this schema and accepting it as conviction, basing their knowledge on it:

Each society has its regime of truth, its 'general politics' of truth: That is, the types of discourse it harbours and causes to function as true; the mechanisms and instances which enable one to distinguish true from false statements, the way in which each is sanctioned; the techniques and procedures which are valorised for obtaining truth; the status of those who are charged with saying what counts as true. (Foucault, 1977, p. 13)

Thus, truth ceases to justify knowledge and becomes an instrument for the hegemonic forms of society, which imposes its view of the world not by violent imposition, but through the different means of socialisation, including media and journalism: "News discourse can be seen as a particular instance of the more general 'will to truth' which motivates and constrains institutional forms of knowing in modern society" (Matheson, 2004, p. 445).

For Foucault, the RoT in place since the modern era is the scientific or epistemological conception of truth, 'truth-demonstration,' targeted on reality and a 'technology of demonstration,' characterised by the omnipresence of truth ("the question of truth can be posed about anything and everything") and universal access to truth, in the sense that the subject, to grasp the truth, relies on "the instruments required to discover it, the categories necessary to think it and an adequate language for formulating it in propositions, and not on the 'mode of being' of the subject himself or herself" (Foucault, as cited in Lorenzini, 2016, p. 64).

Thus, truth, far from being transcendental, is moulded to fit the political, social, economic and cultural environment in which the subject operates, who adopts it 
as their own. Subsequently modifying that environment could lead to a reconsideration of what is true, which would vary according to the new forms of hegemony. This is what may be occurring with neoliberalism, under which a form of individualism that affects the way individuals construct their subjectivity has become more intense. According to David Harvey (2005, p. 23), individualism is one of the foundations of neoliberalism:

All forms of social solidarity were to be dissolved in favour of individualism, private property, personal responsibility and family values. The ideological assault along these lines that flowed from Thatcher's rhetoric was relentless. 'Economic are the method,' she said, 'but the object is to change the soul.'

In the same line, the sociologist Ulrich Beck asserts that individualism is the hallmark of current modernity:

The basic figure of fully developed modernity is the single person....The form of existence of the single person is not a deviant case along the path of modernity. It is the archetype of the fully developed labour market society. The negation of social ties that takes effect in the logic of the market begins in its most advanced stage to dissolve the prerequisites for lasting companionship. (Beck, 1992, pp. 122-123)

This growing individualism has been studied in the field of social communication in relation to the development of new technologies, particularly social media, which are regarded as promoting new models of human relationships such as 'individual networking' or 'networked individualism' (Rainie \& Wellman, 2012). Jayson Harsin (2018) draws a link between these forms of digital communication and an underlying logic focused on recent forms of consumer capitalism, such as the 'attention economy,' in which the problem no longer lies in accessing information, but in how news media capture the audience's attention in increasingly personal and individual ways, segmenting audiences in the same manner as marketing, and in the increasing use of cognitive-oriented commercial tools in political communication and marketing. Maddalena and Gili (2020) agree that the interest of sociology and psychology in understanding human behaviour, in personalising the messages broadcast by commercial, political and media sources, is one of the keys elements in the current individualisation process; one that changes the way individuals, increasingly dependent on their emotions and personal beliefs, think, feel and act. Journalism studies have confirmed this increase in the emotional content of media (Papacharissi, 2014) and the change this is having on information:

As journalism and society change, emotion is becoming a much more important dynamic in how news is produced and consumed. Emphasising emotion as the key redefines the classic idea of journalistic objectivity-indeed, it is reshaping the idea of news itself. (Beckett \& Deuze, 2016, p. 2)

The result of this individualisation process, based on the marketization of information and the primacy of emotional content, would be, according to Harsin, the proliferation of 'truth games' within communication markets devoid of an authority that imposes a truth.

\section{The Reality of News Media: Beyond the Facts}

Maurizio Ferraris warned that the crisis of epistemology in the 20th century has called into question the idea of reality, and that this epistemological confusion may lead to the belief that "the real world ended up being a tale" (Ferraris, 2014, p. 2). Journalism has, until now, been grounded in its faith in facts ('facts are sacred') and has justified this faith through the notion of objectivity. In journalism, epistemological doubts have been formulated almost exclusively in the academic sphere (Muñoz-Torres, 2012), as the journalistic profession has remained a staunch defender of objectivity (Maras, 2013), either as a reflection of reality, as a process in which the truth gradually takes shape or as a ritual through which journalists justify their profession (Tuchman, 1978). Few authors, such as Hearns-Branaman (2016) and his adaptation to Baudrillard's hyperreality, have questioned reality as an a priori. Concern for the ontology of journalism has focused on the emergence of new actors that spread news through social media (Ryfe, 2019).

However, concern about fake news, considered the most visible manifestation of post-truth (Mclntyre, 2018), has indirectly revealed the problem surrounding the ontology of journalism, by reinforcing the objectivist approach to news. Discussion has revolved around defining what constitutes fake news and what it brings to the age-old practice of disinformation (Tandoc, Zheng, \& Ling, 2018), and around offsetting its effects through fact-checkers and media literacy (Wardle \& Derakhshan, 2017). Yet the struggle against fake news remains ineffective (Chan, Jones, Jamieson, \& Albarracín, 2017; Clayton et al., 2020; Thorson, 2016). Pennycook and Rand (2017) cautioned against (a) the limited effect that labelling information as false has on readers and (b) the 'implied truth effect,' i.e., branding certain news as false leads people to believe that the rest has been verified. Other studies have revealed just how little use audiences make of fact-checkers (Guess, Nyhan, \& Reifler, 2018) and the fact that people are unable to perceive a clear difference between fake and real news (Nielsen \& Graves, 2017). These difficulties suggest that perhaps the problem does not reside in finding the correct verification method, but rather in what is verified, in the sense that not all methods allow for the same degree of verification because not all journalistic events allude to the same type of reality. To justify this assertion, we will analyse the typologies of events in journalism based on the hypothesis that, as 
opposed to Ferrari's idea, the heterogeneous nature of these events is causing epistemological confusion. This heterogeneity is not new: Harvey Molotch and Marilyn Lester (1974, p. 106) described it in their research on how "public events" are presented to journalists based on "the circumstances of the promotion work which makes them available to publics." In our analysis of journalistic ontology, we will take the Molotch and Lester typology as a basis and update it with the changes brought about by digital communication.

First, Molotch and Lester refer to 'accidents,' in which (a) the event from which they derive is not intentional and (b) whoever reports it as news has not been affected by the 'accident' or hopes to benefit from it. An 'accident' is a surprise to everyone: to the witnesses of the event, to the journalist who, as a truth-teller, collects the witnesses' accounts, and to the institutions, public or private, affected by the 'accident.' Nonetheless, social media has emerged as a new collector of 'accidents,' interacting with professional truth-tellers (journalists, official sources) as part of a 'hybrid' media system (Chadwick, 2013). People not only provide accounts to the journalist, but are also able to relay them directly to the media sphere: "One thing that crowds do better than journalists is collect data" (Anderson, Bell, \& Shirky, 2012 , p. 24). As a result, the role of the journalist has been thrust into a crisis (Broersma, 2013), and the factual truth of the news media is forced to compete with the truths of non-journalists who are not held to journalistic standards (Deuze \& Witschge, 2017).

The second type of events are 'routine events,' which:

Are distinguishable by the fact that the underlying happenings on which they are presumably based are purposive accomplishments and by the fact that the people who undertake the happening (whom we call 'effectors') are identical with those who promote them into events. (Molotch \& Lester, 1974, p. 106)

There is no surprising occurrence at their origin, but rather a source who creates events, reports them to a journalist (as a witness) and directs their meaning for their benefit. Such is the case of the institutional statements that have colonised the news media (Berkowitz, 2009). These 'verbal manifestations' are a reality whose sole purpose is to be communicated and induce effects through public disclosure. Daniel J. Boorstin (1987) labels them 'pseudo-events,' which he defines as (a) 'not spontaneous,' but rather planned by the party concerned, (b) planted for the purpose of gaining media coverage, (c) discussion surrounding the nature of the event is limited to determining whether it has happened and why, and (d) such events are a self-fulfilling prophecy: Interviewing a 'distinguished' person makes that person distinguished.

The hegemony of institutions as truth-tellers turns 'routine events' into a key tool for political commu- nication and promotional culture, something that has become standardised in journalism through the use of quotes, which should be accurate and balanced. Thanks to this journalistic routine, institutions generate stories about themselves (statements are signs of power) and about the reality they communicate (what they say is real), and they do so by pushing the possibilities of language beyond the strict confines of reality (Hearns-Branaman, 2016). By using Austin's 'speech acts' (1962), we can further explore the linguistic performance of these institutions, which create and spread 'routine events' through: (a) Information locutions, when the institution reports events that cannot be known through other channels (official data, internal events)these events are difficult to verify, unless some manner of internal betrayal occurs, which, as we will see later, would be considered a 'scandal'; (b) illocutionary statements, when the institution mentions something known by the journalist (and audience) to explain, clarify and interpret with a view to fixing the meaning of the event-these statements do not usually provide new facts (except for the statement itself), yet feed public opinion through discussion in the media; (c) perlocutionary statements, when the institution announces it is going to do something-what is newsworthy is the institution's commitment, yet the only verifiable event is the statement, created to be reported by the journalist and for the institution to gauge the audience's reaction, which may generate a verifiable event.

Nonetheless, the power of institutions as truthtellers is being called into question due to two factors: (a) the loss of credibility currently being experienced by all institutions (Edelman, 2020), and (b) social media's capacity to provide individuals direct access to public debates and even constitute an official source when able to capture a collective sentiment and become its spokesperson (Masip, Ruiz, Suau, \& Puertas, 2020), and, in extreme circumstances, even stand as a threat to these institutions, as occurred during the Arab Spring (Wolfsfeld, Segev, \& Sheafer, 2013).

The third type of event are 'scandals,' an anomaly among 'routine events,' in which a source (anonymous) intentionally breaks with the meaning fixed by the institution. This is the category that encompasses 'investigative journalism,' based on revealing what's hidden. A 'scandal' is unexpected for the institution that tries to conceal it, but may be planned by the person who reveals it. Social media greatly increases the chances of there being a 'scandal,' given its unprecedented dissemination capacity, without the intermediary of journalists, as demonstrated by the WikiLeaks case (Marmura, 2018).

The last event type is 'serendipity': The news story originates in an unanticipated event ('accident'), which is handled by an 'effector' (an institution) as if it were a 'routine event.' This occurs when news stories about natural disasters are handled by institutions, as has been the case with the Covid-19 pandemic. With serendipity, different public discourses compete to impose meaning 
on an event, as analysed by agenda setting and framing (D’Angelo, 2019; McCombs, Shaw, \& Weaver, 2014).

Yet, to round off the ontological framework of journalism, a fifth element should be added to the typology proposed by Molotch and Lester, data, given their importance in journalism and their epistemological prestige. Even though behind each datum there is usually an institution (the only entity with the capacity to create it), it is presented as an 'objective witness' of the reality: A seemingly aseptic and neutral 'information package' which lends the news story a factual basis.

The datum operates as a concept: It reduces the complexity of the reality by selecting the quantifiable aspects of an event and discarding all others. Once obtained, the datum may be incorporated into homogeneous datasets to compare, infer or anticipate results. Can a datum be verified? Reality is no help in this regard: it is an abstract of reality, not a raw sample of reality (Rosenberg, 2013). The verification of a datum is methodological (how was it obtained?), although the selection of data used to explain an aspect of reality may always be subject to dispute.

Digitisation has enhanced the ability to use data and has been harnessed by journalism to apply Big Data techniques (Lewis \& Westlund, 2015), intensifying the tendency to datify virtually all aspects of our existence: "Datafication is a contemporary phenomenon which refers to the quantification of human life through digital information, very often for economic value" (Mejias \& Couldry, 2019, p. 1). The datum, when incorporated into a news story, is situated on an ontological level similar to that of facts and statements, despite belonging to substantially different realities (Uscinski \& Butler, 2013).

From this capacity of the news media to compress various realities emerges Baudrillard's notion of 'hyperreality' (Baudrillard, 1994), whereby any element of reality, or fiction, matched by the 'common code' (technological and symbolic) used for dissemination by the media becomes something other than reality (Hearns-Branaman, 2016). Hyperreality is a simulacrum, an illusion of reality through which journalism justifies itself as a profession. Hyperreality replaces the physical reality with the media reality, yet the reality that factcheckers try and verify reduces the media reality to only physical events, ignoring all of the other realities depicted by the news media.

Of these 'public events,' only 'accidents' can be considered verifiable from an objectivist point of view, as they come close to the idea of 'pure fact' without human intervention. Yet reducing all the realities the news media spread to 'accidents' implies leaving out other events, despite the fact that they form the basis of a large amount of news. This is not only an ontological problem: Forcing the objectivist validation of facts shaped by human intervention requires the epistemology to do the impossible.

\section{Epistemology: Just Me}

As we have seen, news media spread news based on facts that people are virtually unable to verify by themselves (Read \& Uçan, 2019), statements by institutional actors who may or may not be trusted, with no details as to how the data were created or for what purpose:

The ability of mere individuals to understand the social world has decreased because they do not have the tools to comprehend what is happening around them or the meaning of events and their consequences, let alone the possibility of directing or influencing those events. (Maddalena \& Gili, 2020, p. 6)

The subject is not only confronted with the media's heterogeneous reality, but, in a digital context, they do so increasingly by themselves, in the sense that the crisis of institutional authority dilutes the global processes of knowledge construction within societies (Berger \& Luhman, 1967) and that digital media and social media tend to isolate the individual in bubbles resistant to any input that jeopardises constructed subjectivity (Fletcher \& Nielsen, 2018; Sunstein, 2018). Katharine Viner (2016) and Jihii Jolly (2014) examined how algorithms heighten this individualisation by personalising searches, prioritising past results and restricting access to new information. While several other studies (Trilling \& Schoenbach, 2015) have dissected the processes of 'selective exposure' in traditional media; a phenomenon intensified by the Internet (Laybats \& Tredinnick, 2016). This results in fragmented audiences and transforms the public sphere, taken to mean a 'general conversation' (the Habermasian public opinion) on the truth of the matter (Sunstein, 2009), dividing it into a series of 'partial conversations' tailored to reflect each group's expectations. Segmentation, typical of marketing, is present in journalistic practices: Tandoc and Vos (2016) dubbed it the 'marketization' of information; for Maria Karidi (2018) it constitutes the application of 'commercial logic' to new media; while, according to Harsin (2015), truth-tellers have become 'Truth markets,' groups competing to impose their truth with no ultimate authority.

A fragmented audience does not imply setting aside the idea of truth, but rather questioning the authority that establishes this truth. In Steve Fuller's (2018) opinion, the battles waged over the truth are not battles of the first order (what is true and what is false), but rather battles of the second order (the criteria of truth and who determines these criteria). For Yael Brahms (2020, p. 16), "In the post-truth era, the power to decide between the narratives is no longer held by the customary sources of authority, but rather, is held by anyone who positions himself opposite these sources of authority."

The lack of authority affects not only truth, but also journalistic facts. An objective reality, such as 'accidents,' implies a single reference, in which sense it would be as authoritative as the truth of correspondence theories 
and pragmatism: There would be only one reality, which remains out there, beyond our control. But facts in which humans intervene, in one way or another, can give rise to what the comedian Stephen Colbert described, in a satirical manner, as 'truthiness': "Everyone was entitled to their own opinion, but not their own facts. But that's not the case anymore. Facts matter not at all" (Rabin, 2006). For Jeffrey Jones, this 'truthiness' represents an emblematic change in the journalistic RoT based on 'truth in fact,' hegemonic until now, which has transformed into an RoT in which a group of actors (citizens, politicians, journalists) create 'believable fictions,' defined as 'constructions of reality where truth in fact is less important than truth in essence. Indeed, the word 'truthiness' is designed to highlight this sleight of hand in the contested terrain of politically motivated constructions of truth" (Jones, 2009, p. 135). Numerous studies have shown how deniers, of everything from vaccines to climate change, reject any scientific fact that does not fit their narratives, and instead accept facts provided by their own supposed experts who reaffirm those narratives (Diethelm \& McKee, 2009).

With fragmented and atomised audiences and a slew of facts with no authority capable of justifying them beyond doubt, what is the criterion of truth in the posttruth era? In the framework of 'truth-demonstration,' a gnostic statement was a 'justified belief,' which forced the subject to leave themselves to validate their statement against reality. But, if emotions and beliefs are at the centre of the new RoT, statements no longer need external validation for the subject to accept them as authentic, making them fundamental constituents of their own subjectivity. In this way, post-truth removes the need for empirical justification. As a result, the statement is reduced to a belief, reinforced by the experience of truth of sincerity, which makes the individual feel good about themselves: That is what Jordi Ibáñez (2017) calls 'collective hedonism.'

This sincerity, if it aspires to stand as justification of knowledge, must be capable of being shared, yet not on the basis of universal reason, as occurs with the RoT of 'truth-demonstration,' but rather through a series of experiences of truth on the same subjects. And a perfect vehicle for this purpose are communities of believers, fostered by the fragmentation of audiences, which are perceived by news media not only as markets for their advertisers, but as reader markets:

Marketing implies attention to market demand. In a period when journalists are faced with shrinking audience sizes, decreasing revenues and an overflow of different forms of audience feedback, pandering to audience choice-that is, giving in to market demand-becomes an easy alternative to privileging editorial autonomy. (Tandoc \& Vos, 2016, p. 13)

Megan Boler and Elizabeth Davis (2018, p. 82) explored how the "affective feedback loop" promoted by social media is a central element in "shaping the networked subjectivity fundamental to computational propaganda and algorithmic governance."

One of the common arguments is that post-truth is just another name for the common lie. Yet participants in one of these communities of believers do not believe they are lying, in the sense that they do not formulate beliefs in which they do not believe, but rather use their belief to justify their knowledge, which is therefore perceived as being certain. And given the adjustment problems that may arise between their beliefs and other beliefs or reality, the subject fills in their knowledge gaps "using a set of beliefs and personal opinions, their sentiments towards this or that politician, their confidence or lack thereof in the various sources of information, and their personal interpretation of the information made public" (Brahms, 2020).

Knowledge gained in this manner finds in news an ideal vehicle for formulating and transmitting itself, since facts, statements and data presented by the news media become meaningful to the individual. News is a story based in reality (Schudson, 2005), albeit the objective reality of correspondence, the social reality of constructivism or Baudrillard's notion of hyperreality. Thanks to this narrative form, the truth of the news does not stem solely from its semantic content, but is part of a Wittgensteinian 'language game' that involves symbolic elements and the rules inherent to any story. The narrative searches for the truth of life, and does not seek to reflect reality as it is (Lule, 2001). This centrality of narration is what Lynn Smith labelled 'narrative turn':

Since the postmodern literary movement of the 1960s swept out of academia and into the wider culture, narrative thinking has seeped into other fields. Historians, lawyers, physicians, economists and psychologists have all rediscovered the power of stories to frame reality, and storytelling has come to rival logic as a way to understand legal cases, geography, illness or war. Stories have become so pervasive, critics fear they have become a dangerous replacement for facts and reasoned argument. (Smith, 2001)

Having removed literal (semantic) meaning as the only means of understanding a text, the statement is relieved of all need for references (D'Ancona, 2017): The fact becomes a free signifier in search of meaning, and the meaning ends up configuring the signifier, not the other way around. The subject, armed with the confidence that their sincerity confers on them, having built their subjectivity in an RoT characterised by individualism, finds no obstacles to prioritising the meaning they want to reaffirm a priori, modelling the signifier at their convenience.

\section{Conclusions}

There is sufficient evidence to support the idea that a change is occurring in the way people perceive reality 
through the news, and that this shift is affecting the perception of what is true or false in the news. While this change has been dubbed 'post-truth,' without specifying exactly what it is, it could really be called anything, because what matters is not the name, but the phenomenon itself. In this article, we have looked to substantiate the term post-truth through what we have called 'epistemological mutation,' which eliminates the subject's need to validate their statements against reality (which was the foundation of the 'truth-demonstration' of the RoT that emerged during the Enlightenment) and replaces it with the sense of security that stems from the sincerity with which the subject formulates their statements, in an context in which individualism has weakened social ties and the construction of knowledge has ceased to be a global endeavour. To substantiate the existence of this mutation, we have framed it within the Foucaultian concept of the RoT, which views epistemology as a product of the hegemonic forms existing in society at a specific moment in history. In this way, this mutation likely corresponds to a change in the RoT resulting from the triumph of a neoliberal form of rationality that has permeated all aspects of life, enhancing individuality and shaping social communication. Digital technologies have accelerated and intensified this change, spreading a neoliberal form of economic logic that tends to reduce human experience to marketing and datafication. We believe that this theoretical interpretative framework could help to pinpoint the origin of some of the current problems (such as the struggle against fake news) and conceptually frame some of the incessant transformations that are taking place in social communication and journalism.

\section{Acknowledgments}

This work was supported by the Ministerio de Ciencia, Innovación y Universidades (Spain) RTI2018-095775-BC44.

\section{Conflict of Interests}

The author declares no conflict of interests.

\section{References}

Anderson, C. W., Bell, E., \& Shirky, C. (2012). Postindustrial journalism: Adapting to the present. New York: NY: Tow Center for Digital Journalism.

Austin, J. L. (1962). How to do things with words. London: Oxford University Press.

Baudrillard, J. (1994). Simulacra and simulation. Ann Arbor, MI: University of Michigan Press.

Beck, U. (1992). Risk society: Towards a new modernity. London: Sage.

Beckett, C., \& Deuze, M. (2016). On the role of emotion in the future of journalism. Social Media + Society, 2(3), $1-6$.
Berger, P., \& Luhman, T. (1967). The social construction of reality: A treatise in the sociology of knowledge. London: Penguin Books.

Berkowitz, D. (2009). Reporters and their sources. In K. Wahl-Jorgensen \& T. Hanitzsch (Eds.), The handbook of journalism studies (pp. 102-115). New York, NY: Routledge.

Biesecker, B. A. (2018). Introduction: Toward an archaeogenealogy of post-truth. Philosophy \& Rhetoric, 51(4), 329-341.

Boler, M., \& Davis, E. (2018). The affective politics of 'post-truth' era: Feeling and networked subjectivity. Emotion, Space and Society, 27, 75-85.

Boorstin, D. J. (1987). The image: A guide to pseudoevents in America (25th ed.). New York, NY: Atheneum.

Brahms, Y. (2020). Philosophy of post-truth. Institute for Nacional Security Studies. Retrieved from https://www.jstor.org/stable/resrep23537?seq=1\# metadata_info_tab_contents

Broersma, M. (2013). A refractuted paradigm: Journalism, hoaxes and the challenge of trust. In C. Peters \& M. Broersma (Eds.), Rethinking journalism: Trust and participation in a transformed news landscape (pp. 28-44). Oxon: Routledge.

Brown, W. (2015). Undoing the demos: Neoliberalism's stealth revolution. New York, NY: Zone Books.

Chadwick, A. (2013). The hybrid media system: Politics and power. Oxford: Oxford University Press.

Chan, M.-P. S., Jones, C. R., Jamieson, K., \& Albarracín, D. (2017). Debunking: A meta-analysis of the psychological efficacy of messages countering misinformation. Psychological Science, 28(11), 1531-1546.

Clayton, K., Blair, S., Busam, J. A., Forstner, S., Glance, J., Green, G., . . . Nyhan, B. (2020). Real solutions for fake news? Measuring the effectiveness of general warnings and fact-check tags in reducing belief in false stories on social media. Political Behaviour, 42, 1073-1095.

Cotoi, C. (2011). Neoliberalism: A Foucauldian perspective. International Review of Social Research, 1(2), 109-124.

D'Ancona, M. (2017). Post truth: The new war on truth and how to fight back. London: Ebury Press.

D'Angelo, P. (2019). Framing theory and journalism. In P. T. Vos, F. Hanusch, A. Sehl, D. Dimitrakopoulou, \& M. Geertsema-Sligh (Eds.), The international encyclopedia of journalism studies (pp. 1-10). New York, NY: Wiley.

Deuze, M., \& Witschge, T. (2017). Beyond journalism: Theorizing the transformation of journalism. Journalism, 19(2), 165-181.

Diethelm, P., \& McKee, M. (2009). Denialism: What is it and how should scientists respond? European Journal of Public Health, 19(1), 2-4.

Edelman. (2020). 2020 Edelman trust barometer. Edelman. Retrieved from https://www.edelman.com/ trustbarometer 
Falomi, M. (2019). Two forms of domination by reason. Nordic Wittgenstein Review, 8, 43-61.

Ferraris, M. (2014). Manifesto of new realism. Albany, NY: The State University of New York Press.

Finlayson, L. (2019). What to do with post-truth. Nordic Wittgenstein Review. 63-79. https://doi.org/ 10.15845/nwr.v8i0.3502

Fletcher, R., \& Nielsen, R. K. (2018). Are people incidentally exposed to news on social media? A comparative analysis. New Media \& Society, 20(7), 2450-2468.

Foucault, M. (1977). The political function of the intellectual. Radical Philosophy, 17, 12-14.

Frankfurt, H. G. (2007). On truth. London: Pimlico.

Fuller, S. (2018). Post truth: Knowledge as a power game. London, Anthem.

Gane, N. (2014). Sociology and neoliberalism: A missing history. Sociology, 48(6), 1092-1106.

Gjorgjioska, M. A., \& Tomici, A. (2019). The crisis in social psychology under neoliberalism: Reflections from social representations theory. Journal of Social Issues, 75(1), 169-188.

Goldstein, R. A., Macrine, S., \& Chesky, N. (2011). Welcome to the "new normal": The news media and neoliberal reforming education. Journal of Inquiry \& Action in Education, 4(1), 112-131.

Guess, A., Nyhan, B., \& Reifler, J. (2018). Selective exposure to misinformation: Evidence from the consumption of fake news during the 2016 U.S. presidential campaign. Brussels: European Research Council. Retrieved from http://www.ask-force.org/web/ Fundamentalists/Guess-Selective-Exposure-toMisinformation-Evidence-Presidential-Campaign2018.pdf

Haack, S. (2019). Post 'post-truth': Are we there yet? Teoria, 85, 25-275.

Harsin, J. (2015). Regimes of posttruth, postpolitics, and attention economies. Communication, Culture \& Critique, 8, 327-333.

Harsin, J. (2018). Post-truth and critical communication. Oxford Research Encyclopedia of Communication. Retrieved from https://oxfordre.com/ communication/view/10.1093/acrefore/978019022 8613.001.0001/acrefore-9780190228613-e-757

Harvey, D. (2005). A brief history of neoliberalism. Oxford: Oxford University Press.

Hearns-Branaman, J. O. (2016). Journalism and the philosophy of truth: Beyond objectivity and balance. New York, NY: Routledge.

Ibáñez, J. (2017). Una introducción [An introduction]. In J. Ibáñez (Ed.), En la era de la posverdad: 14 ensayos [In the era of post-truth: 14 essays] (pp. 11-36). Barcelona: Calambur Editorial.

Jolly, J. (2014, May 20). How algorithms decide the news you see. Columbia Journalism Review. Retrieved from https://archives.cjr.org/news_literacy/algorithms_ filter_bubble.php

Jones, J. P. (2009). Believable fictions: Redactional culture and the will of truthiness. In B. Zelizer (Ed.), The changing faces of journalism: Tabloidization, technology and truthiness (pp. 127-143). New York, NY: Routledge.

Karidi, M. (2018). News media logic on the move? In search of commercial media logic in German news. Journalism Studies, 19(9), 1237-1256.

Kovach, B., \& Rosenstiel, T. (2007). The elements of journalism: What news people should know and the public should expect. New York, NY: Three Rivers Press.

Laybats, C., \& Tredinnick, C. (2016). Post truth, information, and emotion. Business Information Review, 33(4), 204-206.

Lewis, S., \& Westlund, O. (2015). Big data and journalism: Epistemology, expertise, economics, and ethics. Digital Journalism, 3(3), 447-466.

Leyva, R. (2020). Brains, media, and politics: Generating neoliberal subjects. Abingdon and New York, NY: Routledge.

Lorenzini, D. (2016). Foucault, regimes of truth and the making of the subject. In L. Cremonesi, O. Irrera, \& D. Lorenzini (Eds.), Foucault and the making of subjects (pp. 63-76). London and Lanham, MD: Rowman \& Littlefield International.

Luhmann, N. (2000). The reality of mass media. Stanford, CA: Stanford University Press.

Lule, J. (2001). Daily news, eternal stories: The mythological role of journalism. New York, NY: The Guilford Press.

Maddalena, G., \& Gili, G. (2020). The history and theory of pos-truth. London: Palgrave Macmillan.

Maras, S. (2013). Objectivity in journalism. Cambridge: Polity Press.

Marmura, S. (2018). The WikiLeaks paradigm: Paradoxes and revelations. Basingstoke: Palgrave Macmillan.

Masip, P., Ruiz, C., Suau, J., \& Puertas, D. (2020). Media and Twitter agendas for social mobilizations: The case of the protests in defense of the public healthcare system in Spain. International Journal of Communication, 14(2020), 3355-3376.

Matheson, D. (2004). Weblogs and the epistemology of the news: some trends in online journalism. New Media \& Society, 6(4), 443-468.

McCombs, M., Shaw, D. L., \& Weaver, D. H. (2014). New directions in agenda-setting theory and research. Mass Communication and Society, 17, 781-802.

Mclntyre, L. (2018). Post-truth. Cambridge, MA and London: The MIT Press.

Mejias, U. A., \& Couldry, N. (2019). Datafication. Internet Policy Review, 8(4). https://doi.org/10.14763/2019. 4.1428

Molotch, H., \& Lester, M. (1974). News as purposive behavior: On the strategic use of routine events, accidents and scandals. American Sociological Review, 39(1), 101-112.

Muñoz-Torres, J. R. (2012). Truth and objectivity in journalism: Anatomy of an endless misunderstanding. Journalism Studies, 13(4), 566-582.

Nielsen, R. K., \& Graves, L. (2017). “News you don't 
believe": Audience perspectives on fake news. Oxford: Reuters Institute for the Study of Journalism.

Papacharissi, Z. (2014). Affective publics: Sentiment, technology, and politics. Oxford: Oxford University Press.

Pennycook, G., \& Rand, D. G. (2017). Who falls for fake news? The roles of bullshit receptivity, overclaiming, familiarity, and analitic thinking. Journal of Personality, 88(2), 185-200.

Poerksen, B. (2011). The creation of reality: A constructivist epistemology of journalism and journalism education. Charlottesville, VA: Imprint Academic Philosophy Documentation Center.

Prozorov, S. (2019). Why is there truth? Foucault in the age of post-truth politics. Constellations: An International Journal of Critical and Democratic Theory, 26, 18-30.

Rabin, N. (2006, January 25). Interview: Stephen Colbert. A. V. Club. Retrieved from http://tv.avclub.com/ stephen-colbert-1798208958

Rainie, L., \& Wellman, B. (2012). Networked: The new social operating system. Cambridge, MA: MIT Press.

Read, R., \& Uçan, T. (2019). Introduction: 'post-truth'? Nordic Wittgenstein Review. https://doi.org/ 10.15845/nwr.v8i1.3508

Rosenberg, D. (2013). Data before the fact. In L. Gitelman (Ed.), "Raw data" is an oxymoron (pp. 15-40). Cambridge, MA: The MIT Press.

Ryfe, D. (2019). The ontology of journalism. Journalism, 20(1), 206-209.

Schudson, M. (2005). News as stories. In E. Rothenbuhler \& M. Coman (Eds.), Media anthropology (pp. 121-128). Thousand Oaks, CA: Sage.

Smith, L. (2001, November 11). Not the same old story. Los Angeles Times. Retrieved from http://articles. latimes.com/2001/nov/11/news/cl-2758

Sunstein, C. R. (2009). Republic.com 2.0. Princeton, NJ:
Princeton University Press.

Sunstein, C. R. (2018). \#Republic: Divided democracy in the age of social media. Princeton, NJ: Princeton University Press.

Tandoc, E., \& Vos, T. P. (2016). The journalist is marketing the news. Journalism Practice, 10(8), 950-966.

Tandoc, E., Zheng, W. L., \& Ling, R. (2018). Defining "fake news." Digital Journalism, 6(2), 137-153.

Thorson, E. (2016). Belief echoes: The persistent effects of corrected misinformation. Political Communication, 33, 460-480.

Trilling, D., \& Schoenbach, K. (2015). Challenging selective exposure. Digital Journalism, 3(2), 140-157.

Tuchman, G. (1978). Making news: A study in the construction of reality. New York, NY: Free Press.

Uscinski, J. E., \& Butler, R. W. (2013). The epistemology of fact checking. Critical Review: A Journal of Politics and Society, 25(2), 162-180.

Viner, K. (2016, July 12). How technology disrupted the truth. The Guardian. Retrieved from https:// www.theguardian.com/media/2016/jul/12/howtechnology-disrupted-the-truth

Wahl-Jorgensen, K. (2016). Emotion and journalism. In T. Witschge, C. W. Anderson, D. Domingo, \& A. Hermida (Eds.), The SAGE handbook of digital journalism (pp. 128-143). London: SAGE.

Wardle, C., \& Derakhshan, H. (2017). Information disorder: Toward an interdisciplinary framework for research and policy making (Report DGI(2017)09). Strasbourg: Council of Europe.

Williams, B. (2002). Truth and truthfulness. Princeton, NJ: Princeton University Press.

Wolfsfeld, G., Segev, E., \& Sheafer, T. (2013). Social media and the Arab Spring: Politics comes first. The International Journal of Press/Politics, 18(2), 115-137.

\section{About the Author}

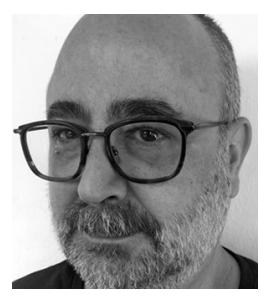

Pablo Capilla is a Journalist and Professor at the Blanquerna School of Communication and International Relations (Ramon Llull University), where he teaches subjects related to journalism, linguistics and international relations. He is also a Professor in the Master's in Political Communication and in the Master of International Journalism at the same university. He is part of the research group "Digilab Media, Strategy and Regulation," which studies innovation in the media and the participation of citizens in the digital public sphere. 